\title{
Navigating selected perceived risk elements on investor trust and intention to invest in online trading platforms
}

\begin{tabular}{|c|c|}
\hline \multicolumn{2}{|c|}{$\begin{array}{l}\text { Authors: } \\
\text { Eugine T. Maziriri }^{1} \text { (1) } \\
\text { Miston Mapuranga }^{2} \text { (1) } \\
\text { Nkosivile W. Madinga }^{3} \text { (D) }\end{array}$} \\
\hline \multicolumn{2}{|c|}{$\begin{array}{l}\text { Affiliations: } \\
{ }^{1} \text { School of Economic and } \\
\text { Business Sciences, University } \\
\text { of the Witwatersrand, } \\
\text { Johannesburg, South Africa }\end{array}$} \\
\hline \multicolumn{2}{|c|}{$\begin{array}{l}{ }^{2} \text { School of Managerial } \\
\text { Leadership, The Da Vinci } \\
\text { Institute for Technology } \\
\text { Management, Lethabong, } \\
\text { South Africa }\end{array}$} \\
\hline \multicolumn{2}{|c|}{$\begin{array}{l}{ }^{3} \text { Department of Marketing, } \\
\text { University of Cape Town, } \\
\text { Cape Town, South Africa }\end{array}$} \\
\hline \multicolumn{2}{|c|}{$\begin{array}{l}\text { Corresponding author: } \\
\text { Eugine Maziriri, } \\
\text { euginemaziriri@gmail.com }\end{array}$} \\
\hline \multicolumn{2}{|c|}{$\begin{array}{l}\text { Dates: } \\
\text { Received: } 11 \text { Nov. } 2018 \\
\text { Accepted: } 20 \text { Feb. } 2019 \\
\text { Published: } 29 \text { July } 2019\end{array}$} \\
\hline \multicolumn{2}{|c|}{$\begin{array}{l}\text { How to cite this article: } \\
\text { Maziriri, E.T., Mapuranga, M. } \\
\text { \& Madinga, N.W., 2019, } \\
\text { 'Navigating selected perceived } \\
\text { risk elements on investor trust } \\
\text { and intention to invest in } \\
\text { online trading platforms', } \\
\text { Journal of Economic and } \\
\text { Financial Sciences 12(1), } \\
\text { a434. https://doi.org/ } \\
\text { 10.4102/jef.v12i1.434 }\end{array}$} \\
\hline \multicolumn{2}{|c|}{$\begin{array}{l}\text { Copyright: } \\
\text { (C) 2019. The Authors } \\
\text { Licensee: AOSIS. This } \\
\text { is licensed under the } \\
\text { Creative Commons } \\
\text { Attribution License. }\end{array}$} \\
\hline \multicolumn{2}{|l|}{ Read online: } \\
\hline 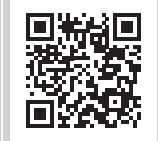 & $\begin{array}{l}\text { Scan this QR } \\
\text { code with your } \\
\text { smart phone or } \\
\text { mobile device } \\
\text { to read online. }\end{array}$ \\
\hline
\end{tabular}

Orientation: In the contemporary global business environment, online trading is a new distribution channel and trading platforms are products of investment and financial services companies.

Research purpose: This study determined the influence of perceived risk elements on investor trust and the intention to invest in online trading platforms among students at a selected university in South Africa.

Motivation for the study: The significance of how perceived risk elements may influence an investor's trust and the intention to invest in online trading has largely been overlooked in previous research. Therefore, the principal objective of this study was to address this research gap.

Research approach, design and method: A structural equation modelling (SEM) procedure was applied to perform the hypotheses testing using the AMOS (version 25.0) package.

Main findings: All the perceived risk elements had a positive and a significant impact on investor trust as well as the intention to invest in online trading platforms.

Practical/managerial implications: This study provides fruitful implications to practitioners. The collective knowledge on dimensions of perceived risk will be advantageous to managers in understanding consumer risk perception and how students attempt to reduce these risks. Hence, this will also help managers to implement risk-reduction strategies in order to increase the prospect of students investing in their online trading platforms.

Contribution/value-add: This study stands to add new knowledge to the present body of investment management and financial management literature in Africa - a context that has not received much research attention in developing countries.

Keywords: perceived security risk; perceived privacy risk; perceived financial risk; perceived fraud risk; investor trust; intention to invest; online trading platforms.

\section{Introduction}

In today's contemporary business environment, most individuals are captivated by the idea of investing their money in online trading platforms (Barber \& Odean 2013). These participants are fascinated by the idea that the forex market works by its own rules and has least transaction costs (Vasile, Teodorescu \& Bucur 2015). In addition, online trading has a lot of compensations, such as faster trading speed, improved data transparency and lower operating cost (Huang, Hung \& Yen 2005; Khan et al. 2018; Lee 2009a), and naturally it is expected that a stock investor will choose to adopt online trading if they perceive that doing so will provide greater benefits than existing methods. Because perceived benefit has been empirically shown to significantly impact Internet adoption (Mehrtens, Cragg \& Mills 2001), affect e-business adoption (Zheng et al. 2006) and influence the corporate website adoption (Beatty, Shim \& Jones 2001), using it in the technologydriven context of online trading is a rational undertaking.

Despite the above, the risk theory of consumer behaviour, as advanced by Bauer (1960), indicates that benefits are often accompanied with risks. The spatial and temporal separation between customers and stock brokerage firms and the unpredictability of the Internet infrastructure generate an implicit uncertainty around online transactions. Firstly, there is the risk of monetary loss because of transaction error or stock account misuse. Secondly, there is the risk of loss of privacy because of Internet fraud or hacker intrusion. The open nature of the Internet as a 
transaction infrastructure and its global nature create uncertainty around online transactions, and this makes trust and risk crucial elements of e-commerce (Bojang 2017; Hoffman, Novak \& Peralta 1999; Pavlou 2003). In addition, Yousafzai, Pallister and Foxall (2003) as well as Yousefi and Nasiripour (2015) argue that the notion of trust is perhaps the most important component of electronic banking transactions. Therefore, perceptions of trust and risk are likely to be important factors in predicting the investor's intention to invest in online trading platforms.

Notwithstanding this noted research interest of online trading - the extant empirical literature related to perceived risk, investor trust and online trading platforms show some gaps, hence the need for further academic introspection. Notably, most international studies have been conducted in countries such as, inter alia, Taiwan, Romania, Austria, Chile, Vietnam and the United States. For example, Vasile et al. (2015) examined perceived risk, investor trust and online trading platforms in Romania (Vasile et al. 2015). Lee (2009) predicted and explained the adoption of online trading in Taiwan, while Trattner et al. (2014) predicted buyer-seller interactions in online trading platforms through social networks. Wang, Wang and Tai (2002) conducted a study on online auction sites in Taiwan, while Chen, Fan and $\mathrm{Li}$ (2016) investigated an advertising versus brokerage model for online trading platforms and Wang and Lee (2005) focused on customer satisfaction towards online shopping at electronics shopping malls in Vietnam.

Despite the growing body of research on online trading platforms, there is still lack of understanding about the impact of perceived security risk, perceived privacy risk, perceived financial risk and perceived fraud risk on investor trust as well as the intention to invest in online trading platforms in Africa. Precisely, within the South African context previous studies have conducted their studies in various contexts by focusing on the relationship between foreign direct investment and economic growth in South Africa (Masipa 2018); a few South African cents' worth on Bitcoin (Nieman 2015); the relationship between the exchange rate and the trade balance in South Africa (Chiloane, Pretorius \& Botha 2014); responsible investing in South Africa (Viviers \& Els 2017); familiarity bias among individual investors (De Vries, Erasmus \& Gerber 2017) and a South African perspective on the investment performance of ethical funds compared to conventional funds and investor behaviour as regards ethical funds (Patel 2016). This shows that there is scant evidence of studies focusing on how perceived security risk, perceived privacy risk, perceived financial risk and perceived fraud risk impact investor trust and the intention to invest in online trading platforms in South Africa. Hence, this warrants the need for the present study.

This article is structured is as follows: firstly, a research context is provided and thereafter the empirical literature is presented, followed by a conceptual model and a hypothesis development. The research design and methodology are then presented, followed by a presentation of the results and the discussions. The final sections of the article discuss the implications, limitations and future research directions.

\section{Research context}

\section{An online trading platform}

As indicated by Baralis et al. (2017), online trading is the procedure by which private investors or traders purchase and offer money-related items or securities through online trading platforms. The example of a trading platform is shown in Figure 1. Ackert et al. (2016) discuss that a great many individuals go on the web each day to express thoughts and gather data on the subjects that worry webbased exchanging and venture tips as opposed to depending entirely on corporate budgetary reports and administration revelations. Consequently, Renault (2016) supplements that in fact messages distributed by online financial specialists on the web are generally shorter and less formal than substance distributed on conventional media. The major standards of online trading are value investing and development contributing. Talledo (2011) states that value investing is a venture methodology which endeavours to purchase stocks whose offer cost is thought little of and development, putting stresses on putting resources into organisations that display indications of better than expected development. Most online traders are clueless about the dangers related to online trading. Accordingly, online trading between two outsiders falls in the domain of a detainee's difficulty (Yamamoto, Ishida \& Jackson 2003).

Consequently, Choi (2016) recommends that if online financial investors just pursued investment advice of nearby merchants, speculators inside a similar neighbourhood would be adequately connected. Be that as it may, Du, Huang and $\mathrm{Li}$ (2012) contend that the crucial component of online trading is that traders are typically mysterious and topographically scattered and this builds the trouble of legitimate implementation of assertions in online markets. Also, Evans (2017) includes that from 2013, administrative specialists and law requirements have been inspecting the forex exchanging exercises of the world's biggest banks, particularly around the time that benchmark forex costs are resolved. Besides, Evans (2017) improves that examinations by regulatory authorities have created penalties and fines on the banks adding up to enormous aggregates of cash that have prompted the rejection or suspension of various bank workers associated with online trading. The number of inhabitants in online trading is colossal that a trader may never need to manage a similar purchaser again as expressed by Zhong et al. (2012). Consequently, Choi and Choi (2018) evaluate that singular individual investors or online traders commonly have constrained access to inside or fundamental data regarding security guarantors. As per Choi and Choi (2018), it ought to be noticed that there is significant proof that people are uninformed traders. Hence, they frequently tend to trade single stocks dependent on mistaken commotion or put resources into shared assets at high expenses instead of building or holding a market portfolio 


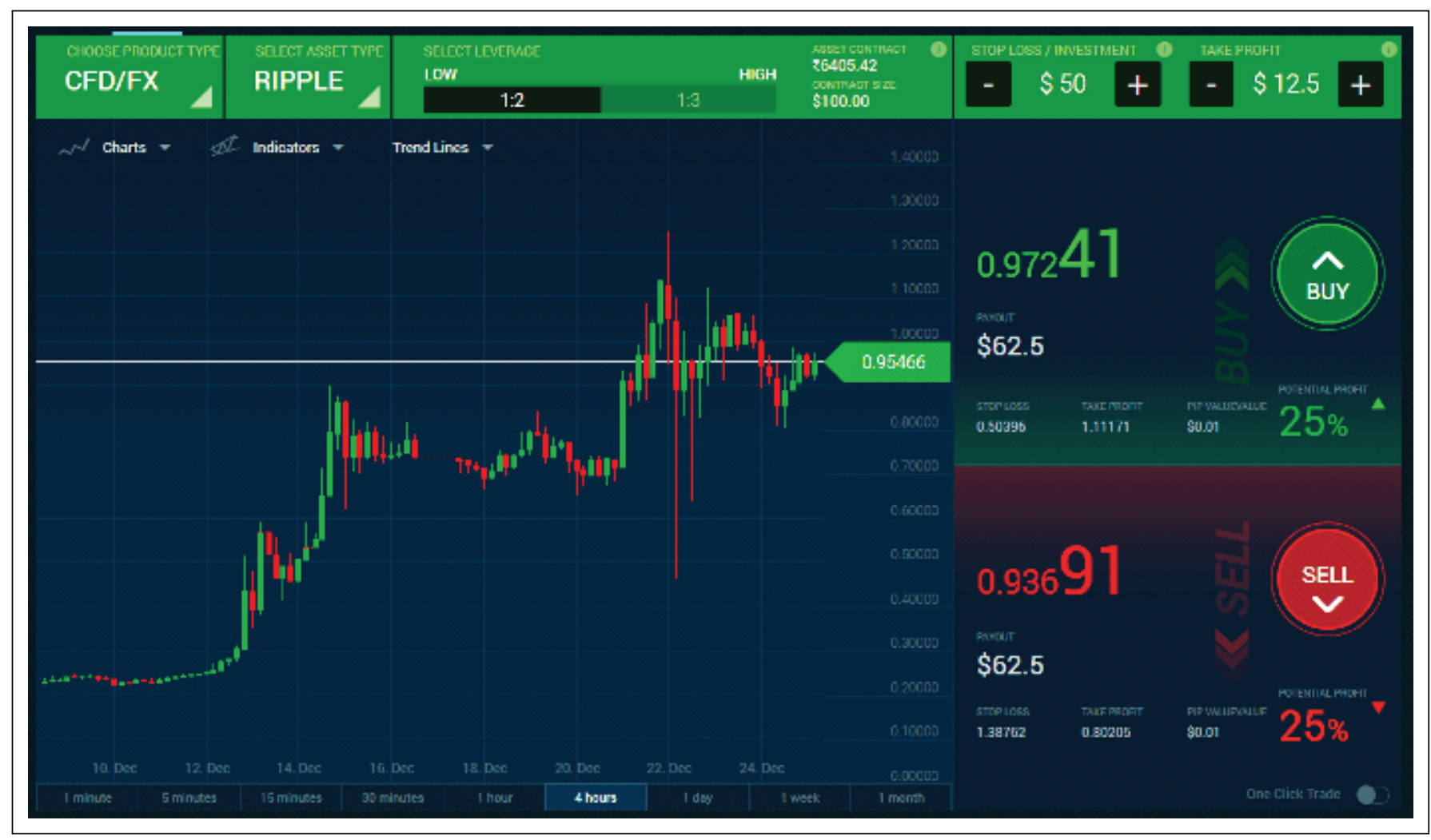

Source: https://wall-street.com/the-benefits-of-online-trading-platforms/ (viewed 01 April 2018) FIGURE 1: An online trading platform.

(Lease, Lewellen \& Schlarbaum 1974). By and by because of the high level of effective traders, online markets always endeavour to enhance their notoriety frameworks to expand market effectiveness (Du et al. 2012).

\section{Online trading activity of university students}

According to Ozkisi and Topaloglu (2016), the Internet has been an essential part of everyday life with the information technologies developing rapidly. Choudhury and Dey (2014) mention that more than $75 \%$ of Internet usage is still driven by youngsters that include young men and school- and college-going students. Several students use the Internet to trade online (Bosch 2009). Hence, students are a rewarding market for financial institutions (Warwick \& Mansfield 2000). Nevertheless, it is also imperative to note that within the existing body of knowledge there are deficiencies in the literature which is focused on the applicability of online trading platforms among university students, hence the need of the current study. A closely related study is the one conducted by Liivamägi (2016), which aimed at determining how investors' educational characteristics affect trading activity on the stock market. The traders, in their sample, were relatively young students and most of the investors belonged to the Y-generation cohort. Applying an ordered logit regression model and controlling for gender, age, wealth, portfolio diversification and average stock holding period, Liivamägi's study provided empirical evidence that the investors with top results in national examinations or the investors holding an academic degree trade stocks more actively. The opposite was true for the investors with no academic degree as they trade stocks less actively (Liivamägi 2016). Another study, which describes the online trading activity of students, is the one conducted by Huang (2015:1) entitled 'China's college students embrace stock trading, thanks to money from mom and dad'. Huang (2015) reported that college students were inundating the online trading markets. The state-run Xinhua news agency stated that there are $31 \%$ of college students who have invested in stocks and of them $26 \%$ put more than 50000 yuan (\$8058) into the activity and lastly $76 \%$ got the money from their parents (Huang 2015). Concluding from the previously mentioned illustrations, it is imperative to note that this examination will be among the investigations that have an exceptional reference to online trading platforms among students.

\section{Empirical literature}

This section of the literature review discusses the different research variables undertaken as part of this study.

\section{Perceived security risk}

Security is the capacity to ensure data against potential dangers or guarantee that a framework can counteract assaults which can imperil information and administrations (Damghanian, Zarei \& Kojuri 2016). Perceived security risk issues have expected more prominent centrality as of late with the approach of web-based business exchanges (Mann \& Sahni 2013). In the online environment, success of e-commerce is subordinate upon the development of ensured security (Kolsaker \& Payne 2002). Perceived security risk is, 
therefore, characterised by Kim, Ferrin and Rao (2008:546) as 'shopper's conviction about the potential dubious negative results from the online transaction'. Furthermore, Dowling and Staelin (1994:119) expound the idea of perceived security risk as 'the shopper's view of the vulnerability and unfavourable results of purchasing a product or a service'.

\section{Perceived privacy risk}

Perceived privacy risk relates to data privacy and is described as Internet users' concerns about their ability to control the collection of their personal information and control the future usage of the collected information or the information that was generated based on their online activities, as stated by Mekovec and Hutinski (2012). In addition, Culnan and Armstrong (1999) argue that concerns regarding the privacy of personal information have been declared a major obstacle of consumer participation in various online activities, including online trading platforms. Furthermore, Sharma and Kurien (2017) argue that by sharing this information, customers perceive potential loss of control over personal information. However, Ginosar and Arial (2017) point out that a website's privacy policy should be considered as a managerial concept or as an integral part of the website's business model.

\section{Perceived financial risk}

According to Hanafizadeh and Khedmatgozar (2015), perceived financial risk refers to customers' concerns about the potential of financial loss. In a similar vein, Maziriri (2016:31) elucidates that 'perceived financial risk involves monetary loss and unexpected costs'. In addition, making appropriate financial decisions is one of the most important choices an individual may face during their lifetime (Brooks et al. 2018). Hence, Bucciol and Miniaci (2018) state that financial risk propensity is the willingness to bear risk, in a time interval that includes recessions as well as expansion periods. Malmendier and Nagel (2011) suggest that the recent shocks to financial market returns might have a long-lasting impact on investors' behaviour and persistently reduce future stock market participation. Kannadhasan (2015) elucidates that financial risk tolerance has explored demographics to play a major role in identifying the financial risk tolerance of the individual.

\section{Perceived fraud risk}

According to Banerjee and Chua (2016), perceived fraud risk occurs online, raising questions about the role of online communities in managing fraud. The Association of Certified Fraud Examiners (ACFE) defines 'fraud' as the use of one's occupation for personal enrichment through the deliberate misuse or misapplication of the using of an organisation's resources or assets (ACFE 2009). Moreover, perceived fraud risk measures a consumer's concerns about a seller's reliability in online shopping (Naiyi 2004). Therefore, for this study perceived fraud risk will be described as any fraud committed through web-based communications such as emails and web-links and profile creation.

\section{Investor trust}

Trust is the core of any relationship (Damghanian, Zarei \& Siahsarani Kojuri 2016). It is a mind-boggling marvel that has impacted human connections and is pivotal for the accomplishment of electronic business. Once there is no entrance to many tools (Connolly and Banister 2007), trust is a psychological certification, and guarantees the customer that the normal favourable circumstances from a dealing is accomplished and furthermore the seller would not act astutely (Wang, Ngamsiriudom \& Hsieh 2015). Also, Hanafizadeh and Khedmatgozar (2012) state that trust makes shoppers happy with sharing individual information, making purchases and taking a shot at a web merchant proposal, the majority of which are practices basic to far reaching appropriation of Internet business. Besides, Oliveira et al. (2017) add that the overall trust that a consumer has in an Internet vendor rests upon the trustworthiness of the merchants; in the event that they are dependable, customers can confide in them, and this can extensively impact their goal to get online. Along these lines, trust might be a crucial part in diminishing perceptions of risk and influences customers to uncover non-open information once offered the suggestion by an e-seller. Nevertheless, for this study investor trust will be described as the customers' apparent belief that the online trading platform is genuine and is equipped for helping them to trade online and eventually create monetary benefit.

\section{Intention to invest in online trading platforms}

Intention is a function of its three direct determinants of attitude towards behaviour, subjective norm and perceived behavioural control (PBC) (Holst \& Iversen 2011; Mhlophe 2015). This construct represents an individual's motivation to conduct a specific behaviour (Armitage \& Conner 2001). It can likewise be viewed as the immediate determinant of behaviour and the precursor for upcoming purchasing decisions (Ajzen 1991). Furthermore, a person will usually act consistent with his or her intention, except in cases where there are unforeseen challenges, for instance lack of skills or resources and opportunities (Mhlophe 2015). Stated in a different way, Holst and Iversen (2011) posit that intention may be used as a proximal measure of behaviour. Shanmugam, Savarimuthu and Wen (2014:239) elucidate that 'intention to use is defined as a measure of the likelihood that a person will adopt an application'. In addition, the 'perceived behavioural control' conceptualised as an antecedent to 'intention' within the theory of planned behaviour is defined as an individual's perception of the easiness of performing a particular behaviour (Ali 2011). In the context of this study, investors may be interested in investing in a particular online trading platform only when they have time and skill to evaluate the company and have money to invest. Therefore, when forming an intention to invest, individual investors normally begin with evaluations of companies' financial positions based on some objective measures such as return on equity, dividend payout ratio and beta (Ali 2011). Next, their enthusiastic impression of 
such assessments may happen as they are endeavouring to legitimise their investing decisions in the companies' stocks (Ali 2011).

\section{Conceptual model and hypotheses development}

A conceptual model describes the relationship between variables investigated in the study (Maziriri, Mapuranga \& Madinga 2018). In addition, Maziriri et al. (2018) add that a schematic diagram of the conceptual model helps the reader to visualise the theorised relationships between the variables in the model, and thus to obtain a quick idea about how you think that the management problem can be solved. In this study, the conceptual model suggests that perceived security risk, perceived privacy risk, perceived financial risk and perceived fraud risk are the predictor variables. In addition, the conceptual model also suggests that investor trust is the mediator variable. Moreover, the dependent or outcome variable for the current study model is intention to invest in online trading platforms. Based on a synthesis of the converging literature related to the research variables, a conceptual model was proposed to guide the empirical study, as shown in Figure 2.

\section{Hypotheses development Perceived security risk and investor trust}

Zhang and Gupta (2016) stress that online security and trustworthiness issues have become increasingly serious and need to be addressed urgently. In their study entitled 'Trust, Risk, Privacy, and Security in e-Commerce', Pennanen, Kaapu and Paakki (2006) found that security has a direct influence on trust. In addition, Thompson, McGill and Wang (2017) added that online consumers are vulnerable to information security threats, as they must independently make decisions about how to protect themselves, often with little understanding of technology or its implications. Unfortunately, there is a lack of investigating on effective and efficient evaluations and measurements for security and

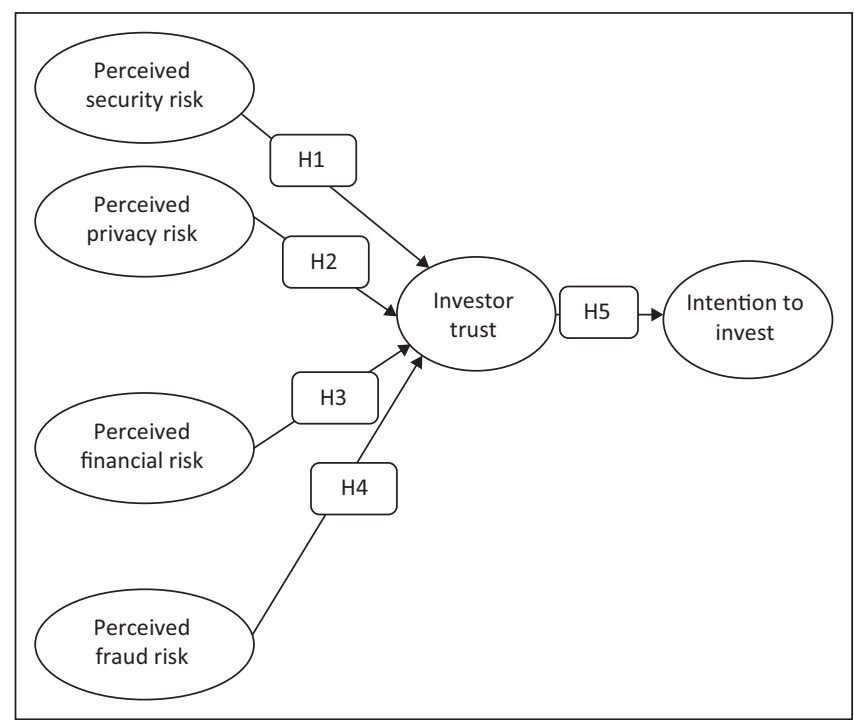

FIGURE 2: Conceptual framework. trustworthiness of various platforms and applications, which has an effect on their further improvement and evolution. Therefore, concluding from the above-mentioned statements, it can be hypothesised that:

H1: Perceived security risk has a positive impact on investor trust among students at a selected university in South Africa.

\section{Perceived privacy risk and investor trust}

Privacy risk and investor trust have received much attention in the literature for their relationships with online transactions (Liao, Liu \& Chen 2017). Hence, Bansal, Zahedi and Gefen (2015) argue that many online business exchanges require the disclosure of sensitive personal information on a regular basis and several factors could influence the extent of customers' trust and their willingness to disclose their private information on online platforms. Therefore, Alemany et al. (2017) claim that users are not often aware of privacy risks and disclose information in online social networks and online platforms and they do not consider the audience that will have access to it. In addition, Bansal, Zahedi and Gefen (2015) further explain that consumer trust is a central determinant of behaviour across situations because it determines the extent to which people are willing to depend on others. Consumers are terrified to disclose confidential information in case the information continues to spread and may reach an unexpected audience. Therefore, drawing from the aforementioned elucidations, it can be hypothesised that:

H2: Perceived privacy risk has a positive impact on investor trust among students at a selected university in South Africa.

\section{Perceived financial risk and investor trust}

It is essential to discuss the nexus between perceived financial risk and investor trust. Nevertheless, the existing literature is limited on this specific subject centred on the relationship between financial risk and investor trust. Hence, that is why Bashir et al. (2018) stated that there seems to be no direct research on the mediating role of consumer trust in the relationship between perceived financial risk and online purchase intention. In addition, Brooks et al. (2018) jointly advise that sometimes the risk tolerance and risk capacity of the consumer are established, even though online consumer trust is affected. Deducing from the aforementioned elucidations, it can be noted that investors may have lower levels of financial risk tolerance and become resistant to engage in online transactions with higher levels of perceived financial risk especially when it emanates from online trading systems, but we are also unable to cover that evidence. Therefore, deducing from the above-mentioned elucidations, it can be hypothesised that:

H3: The financial risk has a positive impact on investor trust among students at a selected university in South Africa.

\section{Perceived fraud risk and investor trust}

It should be noted that there are paucities in studies regarding the relationship between perceived fraud risk and investor trust. However, there are closely related studies that have 
tried to elaborate about this relationship. For instance, Chae et al. (2007) elucidate that online transactions are vulnerable to many types of fraudulent conduct because online marketplace easily attracts fraud as it originates from a unique characteristic of Internet transactions. Therefore, Chae et al. (2007) equally support that the anonymity of the Internet may be preferred by honest traders for the protection of their privacy, while the opportunistic may take advantage of it and commit fraud. Therefore, Chang and Chang (2012) suggest that online consumers need a more proactive approach to protect their profits, such as an early fraud detection system. Therefore, Chen et al. (2015) jointly argue that Alibaba has built a fraud risk monitoring and management system based on real-time big data processing and intelligent risk models that captures fraud signals directly from a huge amount data about user behaviours and networking, analyses them in real-time using machine learning and accurately predicts the bad users and transactions. In addition, Aleem and Antwi-Boasiako (2011) enhance that other Internet auctions sites, including OXL Ricardo, ePier, Amazon and OnSale, have certain mechanisms to prevent fraudulent behaviour and build consumer trust. Therefore, drawing from the aforementioned elucidations, it can be hypothesised that:

H4: Perceived fraud risk has a positive impact on investor trust among students at a selected university in South Africa.

\section{Investor trust and the intention to invest in online trading platforms}

It is imperative to analyse the relation between investor trust and intention to invest in online trading platforms. Chaudhry et al. (2017) proclaim that consumers develop trust and invest more if their neighbour, friends or relatives have invested in the market. Hence, it can be noted that investor trust plays a merger role in online trading platforms. In addition, Wohlgemuth, Berger and Wenzel (2016) jointly assert that consumer trust within online trading communities is a nascent and largely untapped area of research. Hence, Bashir et al. (2018) add that a consumer's intention to invest is influenced by their trust in the online platform. Thus, it can be hypothesised that:

H5: Investor trust has a positive impact on the intention to invest in online trading platforms among students at a selected university in South Africa.

\section{Research methodology}

The research philosophy for this study was positivism. Quantitative research is to be based on a positivist paradigm of measuring variables (Rahman 2016). Hence, for this study a quantitative research approach was utilised. The design was suitable to solicit the required information relating to perceived security risk, perceived privacy risk, perceived financial risk, perceived fraud risk, investor trust and the intention to invest in online trading platforms. In addition, the approach enables one to examine the causal relationships with the constructs used in the study. Being quantitative in nature, the measurement instrument was compiled from several existing scales that were adapted to suit the purpose of the study. Once scale reliability and validity were established, structural equation modelling (SEM) was used to test the model fit, followed by the hypotheses testing and path modelling. Structural equation modelling was performed using AMOS 25 software, and the descriptive statistics were obtained through SPSS 25 software.

\section{Sample and data collection}

The data for this research were collected from students studying at a university within the Johannesburg metropolitan area. These students were conceived as potential investors because they were exposed to finance and investment management education which is aimed to develop the student's knowledge on the discipline of financial markets and trading. Students from the faculty of Commerce, Law and Management at the university in South Africa constituted the sampling frame. With the end goal of this examination, the researchers chose university students as their sample claiming they have not been researched that much in the current literature and in terms of online trading as well as investment management, rather households are the typical group researchers focus their attention on or individuals in a more general sense.

The students had completed a preliminary subject in financial markets and investment management and therefore were considered to have a range of career options. These were individuals on the precarious edge of settling on basic vocation decisions on whether to pursue formal employment or concentrate in being investors in online trading platforms. The researchers chose university students as the target population claiming the objective of the examination was not to establish the actual investment behaviour of respondents, rather investment intentions. Thus, established business owners were inappropriate subjects.

Because the study was based on self-reports of students, the researchers cannot guarantee the durability of the investment intentions of these respondents. In terms of the sampling frame, a list of registered students within the database of the university was used as a sampling frame. Thus, a simple random sampling technique was used in this study because each element of the population had an equal and known chance of being selected as part of the sample (Weideman 2014), for instance every name within the list of students registered within the database of the university had an equal chance of selection. The questionnaires clearly stated that the anonymity of the respondents would be guaranteed and that the study was purely for academic purposes. The Raosoft calculator for sample size was used to calculate the size of the sample (Raosoft Incorporated 2004). The calculation considered the total enrolment of the student population which was of approximately 33346 , a $5 \%$ margin of error, $90 \%$ confidence interval and the recommended $50 \%$ distribution and returned a minimum sample size of 377 respondents. Of the 
377 questionnaires distributed, 261 returned questionnaires were usable, yielding a response rate of $69 \%$.

\section{Data analysis}

Initially, preliminary analysis of the data was conducted using the statistical software SPSS, version 25.0. Thereafter, an SEM procedure was applied to perform the hypotheses testing using the AMOS (version 25.0) package.

\section{The questionnaire design}

Research scales were operationalised based on prior work. Proper modifications were made to fit the current research context and purpose. Perceived security risk had nine items adapted from Hanafizadeh and Khedmatgozar (2012). Perceived privacy risk had nine items adapted from Featherman and Pavlou (2003) as well as Veloutsou and Bian (2008). In addition, perceived financial risk was assessed using six items adapted from Hanafizadeh and Khedmatgozar (2012). Perceived fraud risk was measured using six items adapted from Litter and Melanthiou (2006) and from Hansen, Saridakis and Benson (2018). Furthermore, investor trust was measured with eight items adapted from Ali (2011). Finally, intention to invest in online trading platforms was assessed using nine items adapted from Ali (2011) as well as Pavlou (2003). All were measured on a five-point Likert-type scale, 1 (strongly disagree) to 5 (strongly agree), to express the degree of agreement.

\section{Respondent profile}

Table 1 displays the depiction of the participants. The respondents were requested to report their demographic data, including age, gender, year of study and allowance. Most of the respondents were between the ages of 18-24 years, representing 73.9\%. This was followed by those who were between the ages of 25-29 years, representing $13 \%$ of the total sample. This was then followed by those who were between the ages of 30-35 years, representing $8.4 \%$ of the total sample. The smallest group was those who were above 36 years, representing $4.6 \%$ of the total sample. Table 1 also shows the gender of respondents. The majority of the respondents were male, representing $48.3 \%$ of the total number of the study, followed by female respondents, representing $44.1 \%$. The minority of the respondents who preferred not to state their gender represented $7.7 \%$ of the total number of the study. Table 1 illustrates the year of study of respondents, as well. Most of the respondents were first-year students, representing $33.7 \%$ of the total number of the study, followed by second-year students, representing 29.9\%, then followed by third-year students, representing $22.2 \%$ and, lastly, followed by postgraduate students, representing $14.2 \%$ of the total number of the study. Moreover, Table 1 shows the allowance of respondents. The majority of the respondent's allowance was between 100 and 1000, representing $47.1 \%$ of the total sample, followed by the allowance between 1000 and 2000, representing 30.7\%,
TABLE 1: Sample demographic characteristics.

\begin{tabular}{|c|c|c|}
\hline Characteristics & Frequency & Percentage \\
\hline \multicolumn{3}{|l|}{ Age } \\
\hline $18-24$ years & 193 & 73.9 \\
\hline $25-29$ years & 34 & 13.0 \\
\hline $30-35$ years & 22 & 8.4 \\
\hline Above 36 years & 12 & 4.6 \\
\hline Total & 261 & 100 \\
\hline \multicolumn{3}{|l|}{ Gender } \\
\hline Male & 126 & 48.3 \\
\hline Female & 115 & 44.1 \\
\hline Prefer not to say & 20 & 7.7 \\
\hline Total & 261 & 100.0 \\
\hline \multicolumn{3}{|l|}{ Year of study } \\
\hline 1 year & 88 & 33.7 \\
\hline 2 years & 78 & 29.9 \\
\hline 3 years & 58 & 22.2 \\
\hline Postgraduate & 37 & 14.2 \\
\hline Total & 261 & 100.0 \\
\hline \multicolumn{3}{|l|}{ Allowance } \\
\hline $100-1000$ & 123 & 47.1 \\
\hline $1000-2000$ & 80 & 30.7 \\
\hline 2000-3000 & 25 & 9.6 \\
\hline $3000-4000$ & 13 & 5.0 \\
\hline $4000-5000$ & 9 & 3.4 \\
\hline Above 5000 & 11 & 4.2 \\
\hline Total & 261 & 100.0 \\
\hline
\end{tabular}

followed by the allowance between 2000 and 3000, representing $9.6 \%$, then followed by the allowance between 3000 and 4000, representing 5.0\%, then followed by the allowance between 4000 and 5000, representing 3.4\% and, lastly, followed by the allowance above 5000, representing $4.2 \%$ of the total sample.

\section{Scale accuracy analysis}

The scale accuracy analysis is presented in Table 2 followed by a discussion of the measurement scale reliability and validity.

\section{Reliability}

According to Nunnally (1978), the reliability of a measure is supported if Cronbach's alpha is 0.7 or higher. The results provided in Table 2 range from the lowest Cronbach's alpha (0.837) to the highest (0.956). Cronbach's alpha scores indicated that each construct exhibited strong internal reliability (Lee 2009). Therefore, Cronbach's alpha values of the constructs exceeded the recommended 0.70 , thus meeting the required threshold and demonstrating that the constructs used to measure variables are very reliable for all the variables.

Table 2 shows the loading of each item on their particular construct. The lowest value for each respective item loading for the research constructs is 0.503. Therefore, all the individual item loadings exceeded the recommended value of 0.5 (Anderson \& Gerbing 1988). This indicates that all the measurement instruments are acceptable and reliable because all the individual items converged well and with 
TABLE 2: Scale accuracy analysis.

\begin{tabular}{|c|c|c|c|c|c|c|c|c|c|}
\hline \multirow[t]{2}{*}{ Research constructs } & \multicolumn{4}{|c|}{ Descriptive statistics } & \multicolumn{2}{|c|}{ Cronbach's test } & \multirow[t]{2}{*}{ CR } & \multirow[t]{2}{*}{ AVE } & \multirow{2}{*}{$\begin{array}{l}\text { Factor } \\
\text { loadings }\end{array}$} \\
\hline & Mean value & Scale mean & SD & Scale SD & Item total & $\alpha$ & & & \\
\hline \multicolumn{10}{|c|}{ Perceived security risk (PSR) } \\
\hline PSR1 & 3.480 & \multirow{9}{*}{3.660} & 1.302 & \multirow{9}{*}{1.245} & 0.644 & \multirow{9}{*}{0.919} & \multirow{9}{*}{0.916} & \multirow{9}{*}{0.550} & 0.638 \\
\hline PSR2 & 3.690 & & 1.257 & & 0.690 & & & & 0.683 \\
\hline PSR3 & 3.670 & & 1.220 & & 0.780 & & & & 0.794 \\
\hline PSR4 & 3.730 & & 1.267 & & 0.788 & & & & 0.818 \\
\hline PSR5 & 3.740 & & 1.236 & & 0.753 & & & & 0.810 \\
\hline PSR6 & 3.550 & & 1.153 & & 0.640 & & & & 0.686 \\
\hline PSR7 & 3.630 & & 1.215 & & 0.687 & & & & 0.743 \\
\hline PSR8 & 3.750 & & 1.275 & & 0.726 & & & & 0.759 \\
\hline PSR9 & 3.700 & & 1.287 & & 0.706 & & & & 0.722 \\
\hline \multicolumn{10}{|c|}{ Perceived privacy risk (PPR) } \\
\hline PPR1 & 3.420 & \multirow{8}{*}{3.652} & 1.263 & \multirow{8}{*}{1.198} & 0.512 & \multirow{8}{*}{0.905} & \multirow{8}{*}{0.900} & & 0.571 \\
\hline PPR2 & 3.570 & & 1.201 & & 0.737 & & & & 0.758 \\
\hline PPR4 & 3.630 & & 1.196 & & 0.718 & & & & 0.729 \\
\hline PPR5 & 3.640 & & 1.156 & & 0.755 & & & 0.502 & 0.766 \\
\hline PPR6 & 3.520 & & 1.235 & & 0.621 & & & & 0.623 \\
\hline PPR7 & 3.620 & & 1.197 & & 0.640 & & & & 0.668 \\
\hline PPR8 & 3.750 & & 1.199 & & 0.694 & & & & 0.750 \\
\hline PPR9 & 3.830 & & 1.138 & & 0.713 & & & & 0.764 \\
\hline Perceived financial ri & & & & & & & & & \\
\hline PFIR1 & 3.570 & & 1.233 & & 0.611 & & & & 0.675 \\
\hline PFIR2 & 3.590 & & 1.213 & & 0.595 & & & & 0.620 \\
\hline PFIR3 & 3.570 & 3620 & 1.135 & 1202 & 0.565 & 089 & 0850 & 0187 & 0.612 \\
\hline PFIR4 & 3.600 & 3.038 & 1.227 & 1.202 & 0.680 & 0.848 & 0.850 & 0.481 & 0.771 \\
\hline PFIR5 & 3.700 & & 1.222 & & 0.638 & & & & 0.731 \\
\hline PFIR6 & 3.800 & & 1.205 & & 0.697 & & & & 0.762 \\
\hline Perceived fraud risk ( & & & & & & & & & \\
\hline PFR3 & 3.790 & הבר & 1.127 & 198 & 0.773 & م & ค口ค & 0912 & 0.830 \\
\hline PFR4 & 3.740 & 3.134 & 1.154 & 1.100 & 0.756 & 0.905 & 0.904 & 0.613 & 0.817 \\
\hline PFR5 & 3.700 & & 1.082 & & 0.768 & & & & 0.785 \\
\hline PFR6 & 3.750 & & 1.145 & & 0.703 & & & & 0.708 \\
\hline Investor trust (IT) & & & & & & & & & \\
\hline IT2 & 3.760 & & 1.263 & & 0.577 & & & & 0.539 \\
\hline IT3 & 3.720 & & 1.166 & & 0.611 & & & & 0.546 \\
\hline IT4 & 3.700 & & 1.156 & & 0.591 & & & & 0.509 \\
\hline IT5 & 3.170 & 3.471 & 1.226 & 1.244 & 0.565 & 0.837 & 0.830 & 0.420 & 0.592 \\
\hline IT6 & 3.110 & & 1.339 & & 0.561 & & & & 0.703 \\
\hline IT7 & 3.270 & & 1.317 & & 0.601 & & & & 0.800 \\
\hline IT8 & 3.330 & & 1.243 & & 0.521 & & & & 0.774 \\
\hline Intention to invest in & g platforms (IT & TP) & & & & & & & \\
\hline ITIOTP1 & 3.110 & & 1.358 & & 0.727 & & & & 0.827 \\
\hline ITIOTP2 & 3.140 & & 1.280 & & 0.845 & & & & 0.876 \\
\hline ITIOTP3 & 3.120 & & 1.288 & & 0.869 & & & & 0.864 \\
\hline ITIOTP4 & 3.110 & & 1.314 & & 0.787 & & & & 0.871 \\
\hline ITIOTP5 & 3.110 & 3.149 & 1.340 & 1.328 & 0.838 & 0.956 & 0.959 & 0.712 & 0.850 \\
\hline ITIOTP6 & 3.130 & & 1.340 & & 0.830 & & & & 0.795 \\
\hline ITIOTP7 & 3.180 & & 1.343 & & 0.830 & & & & 0.897 \\
\hline ITIOTP8 & 3.300 & & 1.317 & & 0.852 & & & & 0.865 \\
\hline ITIOTP9 & 3.130 & & 1.375 & & 0.807 & & & & 0.736 \\
\hline
\end{tabular}

SD, standard deviation; $C R$, composite reliability; AVE, average variance extracted.

more than $50 \%$ of each item's variance shared with its respective construct (Fraering \& Minor 2006).

Composite reliabilities (CR) and average variance extracted (AVE) for each construct were also computed using the formulae proposed by Fornell and Lacker (1981:22), that is,

\section{$\mathrm{CR} \eta=(\Sigma \lambda \mathrm{yi}) 2 /[(\Sigma \lambda \mathrm{yi}) 2+(\Sigma \varepsilon \mathrm{i})]$}

where $\mathrm{CR} \eta$ is the composite reliability, $(\Sigma \lambda \mathrm{yi}) 2$ is the square of the summation of the factor loadings and $\left(\sum \varepsilon i\right)$ is the summation of error variances.

$\mathrm{V \eta}=\Sigma \lambda \mathrm{yi} 2 /(\Sigma \lambda \mathrm{yi} 2+\Sigma \varepsilon \mathrm{i})$ 
where $\mathrm{V} \eta$ is the AVE, $\Sigma \lambda y$ i2 is the summation of the squared of factor loadings and $\Sigma \varepsilon i$ is the summation of error variances.

As shown from the results in Table 2, the least CR value of 0.83 is well above the recommended 0.6 (Hulland 1999), while the lowest obtained AVE value of 0.42 is also above the recommended 0.4 (Fraering \& Minor 2006). This indicates that convergent validity was achieved, and this further confirms an excellent internal consistency and reliability of the measurement instruments used. 'As such, all pairs of constructs revealed an adequate level of discriminant validity (see Table 2). By and large, these results provided evidence for acceptable levels of research scale reliability' (Chinomona \& Chinomona 2013:20; Chinomona \& Mofokeng 2016).

\section{Discriminant validity}

The inter-construct correlation matrix is used to assess the validity of measurement instruments, specifically discriminant validity. Correlations among constructs were evaluated to see if they were lower than 1 . The higher the correlation between variables is, the lower the validity of those variables. The inter-construct values are required to be below 0.6 and in some cases below 0.85 to indicate discriminant validity. According to Table 3, the highest correlation value was 0.668 and the lowest correlation value was 0.030. These correlation values are below 0.85 and, therefore, it can be concluded that there is discriminant validity between all the constructs (Morar et al. 2015).

\section{Ethical considerations}

Permission was granted through the research protocol graduate committee of one particular university within the Johannesburg metropolitan area. The researchers acquired the Ethics Clearance certificate from the designated Ethics Committee at the university before questionnaires were given out to respondents. The protocol number was H17/06/26. Ethical consideration was approved unconditionally and this research study acted in accordance with the ethical standards of academic research, which among other things is protecting the identities and interest of respondents and assuring confidentiality of information provided by the participants. Respondents gave their informed consent to this research and were informed beforehand about the reason and the nature of the investigation to ensure that participants were not misled. Despite all the abovementioned precautions, it was made clear to the participants

TABLE 3: Correlation matrix.

\begin{tabular}{lcccccc}
\hline Variable & PSR & PPR & PFIR & PFR & IT & ITIOTP \\
\hline PSR & 1 & - & - & - & - & - \\
PPR & $0.587^{*}$ & 1 & - & - & - & - \\
PFIR & $0.517^{*}$ & $0.669 *$ & 1 & - & - & - \\
PFR & $0.499^{*}$ & $0.576^{*}$ & $0.668^{*}$ & 1 & - & - \\
IT & $0.300^{*}$ & $0.412^{*}$ & $0.451 *$ & $0.490 *$ & 1 & - \\
ITIOTP & 0.030 & 0.122 & 0.119 & 0.097 & $0.593^{*}$ & 1 \\
\hline
\end{tabular}

PSR, perceived security risk; PPR, perceived privacy risk; PFIR, perceived financial risk; PFR perceived fraud risk; IT, investor trust; ITIOTP, intention to invest in online trading platforms.

*, Correlation is significant at the 0.01 level (two-tailed). that the research was only for academic research purpose and their participation in it was absolutely voluntary. No one was forced to participate.

\section{Structural equation modelling Measurement model evaluation}

A confirmatory model development strategy was followed to confirm the dimensional structure of the constructs used in this research as well as the level of internal consistency among the respective indicators. Precisely, a measurement model was specified using maximum likelihood extrapolation (MLE) technique. Initial model estimation was extrapolated at $\mathrm{CMIN} / \mathrm{DF}=2.464(<3.0) ; p<0.01$. It is imperative to note that the significant $\chi^{2}$ value is disregarded by researchers because of sensitivity of the index to large sample sizes and many indicators (Malhotra 2010). To overcome this limitation, Byrne (2010:77) proffers that a more 'pragmatic approach is to report on multiple indices that are not based on the central distribution'. Therefore, the following indices demonstrated adequate model fit as follows: CMIN/DF 1.711, CFI 0.919, GFI 0.798, NFI 0.827, TLI 0.912 and RMSEA 0.052. Figure 2 depicts the CFA model.

\section{Structural model assessment and hypothesis testing}

Results of the structural model analysis indicated that all the structural model fit statistics were within the tolerable ranges: $\chi^{2} / \mathrm{df}=1.711 ; \mathrm{CFI}=0.919, \mathrm{IFI}=0.920 ; \mathrm{TLI}=0.912$; RMSEA $=0.052$. A good fit is normally deemed to exist when NFI, GFI and CFI are all greater than 0.9 (Chang and Chen 2009). Moreover, Figure 3 depicts a structure model. A structural model examination aims to evaluate strength and direction of relationships among constructs in a model (Lee 2009). Table 4 provide results from the structural equation modelling (SEM) analysis.

\section{Outcome of hypotheses testing}

In this study, testing of the hypotheses was determined by path coefficient values as well as the $p$-values for the structural model. In the model, relationships of constructs proposed in this study generate the coefficients of paths. Based on these coefficients, hypotheses are examined.

\section{Outcome of testing hypothesis 1}

Hypothesis 1 states that 'perceived security risk has a positive impact on investor trust'. Based on the results of the final model testing, the relationship between perceived security risk and investor trust shows a $\beta=0.321$ at $p<0.01$. This evidence demonstrates that hypothesis 1 is supported. Hence, it can be noted that students perceive security risk in investing in online trading platforms. It is also worth mentioning that these findings reinforce the results obtained in the study of Salimon and Yusoff (2015), who established that perceived security has an influence on e-banking trust. 


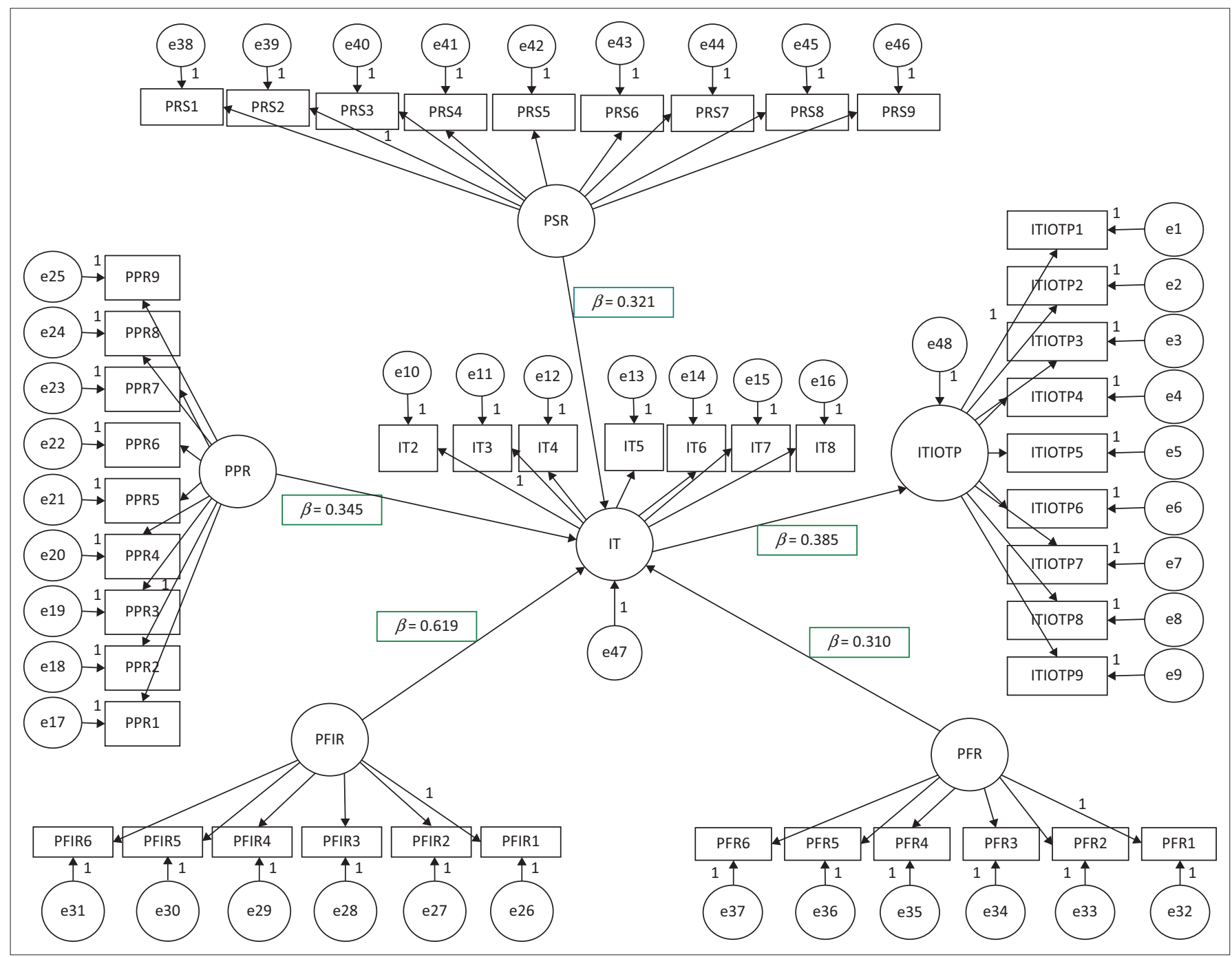

PSR, perceived security risk; PPR, perceived privacy risk; PFIR, perceived financial risk; PFR, perceived fraud risk; IT, investor trust; ITIOTP, intention to invest in online trading platforms. FIGURE 3: Final structural model of the study.

TABLE 4: Summary of the hypotheses testing.

\begin{tabular}{lcccc}
\hline Relationships & Hypothesis & Path coefficient & $\boldsymbol{p}$ & Remarks \\
\hline IT $\leftarrow$ PSR & H1 & 0.321 & $* * *$ & Supported \\
IT $\leftarrow$ PVR & H2 & 0.345 & $* * *$ & Supported \\
IT $\leftarrow$ PFIR & H3 & 0.619 & $* * *$ & Supported \\
IT $\leftarrow$ PFR & H4 & 0.310 & $* * *$ & Supported \\
ITIOTP $\leftarrow$ IT & H5 & 0.385 & $* * *$ & Supported \\
\hline
\end{tabular}

PSR, perceived security risk; PFIR, perceived financial risk; PFR, perceived fraud risk IT, investor trust; ITIOTP, intention to invest in online trading platforms.

$* * *$, significance level $p<0.01$.

\section{Outcome of testing hypothesis 2}

Hypothesis 2 asserts that 'perceived privacy risk has a positive impact on investor trust'. The final structural model presents the relationship between perceived privacy risk and investor trust results in a coefficient $\beta=0.345$ at $p<0.01$. Thus, hypothesis 2 is supported. These results mean that students perceive some privacy risk in investing in online trading platforms. It is also essential to mention that these findings corroborate the results obtained in the works of Gurung, Luo and Raja (2008), who elucidated that consumer's concerns about privacy influence how the consumer will trust an online company or perceive risk in purchasing from the company.

\section{Outcome of testing hypothesis 3}

Hypothesis 3 states that 'perceived financial risk has a positive impact on investor trust'. Based on the results of the final model testing, the relationship between perceived financial risk and investor trust shows a $\beta=0.619$ at $p<0.01$. This evidence demonstrates that hypothesis 3 is supported. In addition, these results imply that students perceive some finance risk in investing in online trading. The results obtained in this study are also in accord with Durmus, Ulusu and Akgun (2017), who examined the effect of perceived risks on online purchase intention through word of mouth and trust issues. Their study revealed that financial fisk has an effect on trust.

\section{Outcome of testing hypothesis 4}

Hypothesis 4 asserts that 'perceived fraud risk has a positive impact on investor trust'. The final structural model presents the relationship between perceived fraud risk and investor trust results in a coefficient $\beta=0.310$ at $p<0.01$. Thus, hypothesis 4 is supported. This means that students perceive some fraud risk by investing in online trading. The result 
obtained from testing this hypothesis is also in agreement with the literature. For instance, Rofiq (2012) emphasised that customers are reluctant to undertake e-commerce transactions if they perceive that cyber-fraud will threaten their decisions. Perceptions can be generated from incidents they have experienced or information they receive via friends and the press (Rofiq 2012).

\section{Outcome of testing hypothesis 5}

Hypothesis 5 states that 'investor trust has a positive impact on the intention to invest in online trading platforms'. Based on the results of the final model testing, the relationship between investor trust and the intention to invest in online trading platforms shows a $\beta=0.385$ at $p<0.01$. This evidence demonstrates that hypothesis 5 is supported. Hence, it can be stated that students perceive some trust risk when they want to invest in online trading. The results obtained in the current study are also not without empirical support. Empirical research has shown that trust increases customer intention to purchase a product from a company (Jarvenpaa, Tractinsky \& Vitale 2000) as well as behavioural intention to return to that company (Doney \& Cannon 1997). In addition, the findings obtained in this study have ample support from previous empirical research studies, such as the one conducted by Durmus et al. (2017), who found that trust has an effect on online purchase intention.

\section{Recommendations and contributions of the study}

According to Maziriri (2016:129), in-depth information, as a result of high involvement, functions to reduce risk and uncertainty. Known brands, knowledgeable sales staff and guarantees of satisfaction can help reduce perceived risks (Maziriri 2016:130). Consequently, it very well may be noticed that if students are exceptionally included with different online trading products and online trading financial companies, they will have more prominent learning of online trading. Truth be told, their trust in the choice of online trading platforms and their intention to invest in online trading platforms will be expanded, which prompts fewer students encountering perceived risk. The study will also be beneficial to online marketing managers, academicians and government. With regard to online marketing managers, the collective knowledge on the dimensions of perceived risks to invest on online trading systems will be advantageous to them in understanding consumer risk perception and how students attempt to reduce these risks. Therefore, this will help managers to implant risk-reduction strategies within the web-based systems to increase the prospect of students investing in their online trading platforms. Further studies have supported the notion, stated by Wallace and Sheetz (2014), that technology acceptance model purports that if a technology or innovation improves a person's performance and does not greatly increase the effort required to perform a function, it is considered useful and easy to use and the person will be more likely to adopt the technology, service or behaviour. To academicians, the study can be used as a foundation for further evaluation and expansion on literature to determine strategies for risk reduction to attract online trading customers such as university students. To the government, the study can be used during the enforcement of contracts to financial institutions as well as during policy implementation.

\section{Limitations and future research directions}

The discoveries from this examination probably cannot be generalisable to students at other South African institutions of higher learning given the comparatively small student sample utilised and the investigation's core interest in a solitary university. Hence, future examinations ought to coordinate students from other institutions to expand the representativeness of the sample. Furthermore, focusing on university students just confines the generalisability of the discoveries as they do not speak to the entire populace of potential investors on online trading platforms, and, subsequently, different students at different secondary schools and other training academies ought to be incorporated into future investigations. In conclusion, the examination's quantitative character may have prompted the disregard of more illuminating and more extravagant information, which a qualitative methodology could have created had it been converged in the investigation. If need be, future examinations can investigate indistinguishable point from the present examination utilising a mixed method technique to upgrade the expansiveness of the examination results.

\section{Conclusion}

The primary purpose of this study was to provide direction for future research by developing a theory-based model for the intention to invest in online trading platforms among university students at a particular university in Johannesburg, South Africa. Online marketing managers can consider some insights from this study to improve consumer trust by developing a more positive attitude and enhancing loyalty towards the consumer's intention to invest in the online trading systems. Managers should also stay abreast of the recommendations that are shared online on social networks and online trading community websites. These recommendations, feedback and commentaries have a great impact on the attitude of students towards online trading. Therefore, managers should highly get involved by facilitating recommendations posted online by communities and other users to foster a more positive consumer attitude towards (behaviour) the intention to invest in online trading platforms.

\section{Acknowledgements}

The authors would like to thank the editor and all the anonymous reviewers for their invaluable comments and feedback, and also the students who responded to this study. 


\section{Competing interests}

The authors declare that they have no financial or personal relationships that may have inappropriately influenced them in writing this article.

\section{Authors' contributions}

E.T.M. was the project leader, formulated the concept, devised the structure of the paper, wrote the article and analysed the collected data. M.M. and N.W.M. were responsible for the review of empirical literature as well as writing the research design and methodology of this article. All the authors conducted the interviews with the respondents.

\section{Funding}

This research received no specific grant from any funding agency in the public, commercial, or not-for-profit sectors.

\section{Data availability statement}

Data sharing is not applicable to this article as no new data were created or analysed in this study.

\section{Disclaimer}

The views and opinions expressed in this article are those of the authors and do not necessarily reflect the official policy or position of any affiliated agency of the authors.

\section{References}

Ackert, L.F., Jiang, L., Lee, H.S. \& Liu, J., 2016, 'Influential investors in online stock forums', International Review of Financial Analysis 45, 39-46. https://doi.org/ forums', International Review
$10.1016 / \mathrm{j}$.irfa.2016.02.001

Ajzen, I., 1991, 'The theory of planned behavior', Organizational Behavior and Human Decision Processes 50(2), 179-211. https://doi.org/10.1016/0749-5978(91)90020-T

Aleem, A. \& Antwi-Boasiako, A., 2011, 'Internet auction fraud: The evolving nature of online auctions criminality and the mitigating framework to address the threat' International Journal of Law, Crime and Justice 39(3), 140-160. https://doi.org/ 10.1016/j.ijlcj.2011.05.003

Ali, A., 2011, 'Predicting individual investors' intention to invest: An experimental analysis of attitude as a mediator', International Journal of Human and Socia Sciences 6(1), 57-73.

Armitage, C.J. \& Conner, M., 2001, 'Efficacy of the theory of planned behavior: A metaanalytic review', British Journal of Social Psychology 40, 471-499. https:// doi.org/10.1348/014466601164939

Association of Certified Fraud Examiners, 2009, Insurance fraud handbook, viewed 25 October 2018, from https://www.acfe.com/uploadedFiles/ACFE_Website/.../ Insurance-Fraud-Handbook.pdf.

Banerjee, S. \& Chua, A.Y., 2016, 'In search of patterns among travellers' hotel ratings in TripAdvisor', Tourism Management 53, 125-131.

Baralis, E., Cagliero, L., Cerquitelli, T., Garza, P. \& Pulvirenti, F., 2017, 'Discovering profitable stocks for intraday trading', Information Sciences 405, 91-106. https:// doi.org/10.1016/j.ins.2017.04.013

Barber, B.M. \& Odean, T., 2013, 'The behavior of individual investors', Handbook of the Economics of Finance 1(2), 1533-1570. https://doi.org/10.1016/B978-0-44459406-8.00022-6

Bashir, S., Anwar, S., Awan, Z., Qureshi, T.W. \& Memon, A.B., 2018, 'A holistic understanding of the prospects of financial loss to enhance shopper's trust to search, recommend, speak positive and frequently visit an online shop', Journo of Retailing and Consumer Services 42, 169-174. https://doi.org/10.1016/j. jretconser.2018.02.004

Bauer, R.A., 1960, 'Consumer behavior as risk taking', in Proceedings of the 43rd National Conference of the American Marketing Association, Chicago, IL, $15-17$ th June.

Beatty, R.C., Shim, J.P. \& Jones, M.C., 2001, 'Factors influencing corporate web site adoption: A time-based assessment', Information \& Management 38(6), 337-354. https://doi.org/10.1016/S0378-7206(00)00064-1

Bojang, I., 2017, 'Determinants of trust in B2c e-commerce and their relationship with consumer online trust: A case of Ekaterinburg, Russian Federation', The Journal of Internet Banking and Commerce 22, 1-59.
Bosch, T.E., 2009, 'Using online social networking for teaching and learning: Facebook use at the University of Cape Town', Communication 35(2), 185-200. https//doi. org/10.1080/02500160903250648

Brooks, C., Sangiorgi, I., Hillenbrand, C. \& Money, K., 2018, 'Why are older investors less willing to take financial risks?', International Review of Financial Analysis 56, 52-72. https://doi.org/10.1016/j.irfa.2017.12.008

Bucciol, A. \& Miniaci, R., 2018, 'Financial risk propensity, business cycles and perceived risk exposure', Oxford Bulletin of Economics and Statistics 80(1), 160-183. https:// doi.org/10.1111/obes.12193

Byrne, B.M., 2010, Structural equation modelling with AMOS: Basic concepts, applications and programming, 2nd edn., Routledge, New York.

Chae, M., Shim, S., Cho, H. \& Lee, B., 2007, 'An empirical analysis of fraud detection in online auctions: Credit card phantom transaction', in System Sciences, HICSS 2007, 40th Annual Hawaii International Conference on IEEE, 3-6th January, p. 155a.

Chang, H.H \& Chen, S.W., 2009, 'Consumer perception of interface quality, security, and loyalty in electronic commerce', Information \& Management 46, 411-417. https://doi.org/10.1016/j.im.2009.08.002

Chaudhry, N.I., Jariko, M.A., Soomro, A.F., Gafoor, M. \& Bilal, A., 2017, 'Evaluating impact of word-of-mouth communication on investor's behavioral intention: An empirical evidence from Pakistan's stock market', European Journal of Business and Social Sciences 6(02), 287-301. https://doi.org/10.1080/15427560.2014.914029

Chen, J., Fan, M. \& Li, M., 2016, 'Advertising versus brokerage model for online trading platforms', MIS Quarterly 40(3), 575-596. https://doi.org/10.2139/ssrn.2164380

Chiloane, L., Pretorius, M. \& Botha, I., 2014, 'The relationship between the exchange rate and the trade balance in South Africa', Journal of Economic and Financial Sciences 7(2), 299-314.

Chinomona, E. \& Mofokeng, T.M., 2016, 'Impact of organisational politics on job dissatisfaction and turnover intention: An application of social exchange theory on employees working in Zimbabwean Small and Medium Enterprises (SMEs) Journal of Applied Business Research 32(3), 857-871. https://doi.org/10.19030/ jabr.v32i3.9661

Chinomona, R. \& Chinomona, E., 2013, 'The influence of employees' perceptions of organizational politics on turnover intentions in Zimbabwe's SME sector' South African Journal of Business Management 44(2), 15-24. https://doi. org/10.4102/sajbm.v44i2.156

Choi, P.M.S. \& Choi, J.H., 2018, 'Is individual trading priced in stocks?', Journal of International Money and Finance 85, 76-92. https://doi.org/10.1016/j.jimonfin. 2018.03.004

Choi, S., 2016, 'Herding among local individual investors: Evidence from online and offline trading', Economics Letters 144, 4-6. https://doi.org/10.1016/j.econlet. 2016.04.030

Choudhury, D. \& Dey, A., 2014, 'Online shopping attitude among the youth: A study on university students', International Journal of Entrepreneurship and Development Studies 2(1), 23-32.

Connolly, R. \& Bannister, F., 2007, 'Consumer trust in Internet shopping in Ireland: Towards the development of a more effective trust measurement instrument', Journal of Information Technology 22, 102-18. https://doi:10.1057/palgrave. jit.2000071

Culnan, M.J. \& Armstrong, P.K., 1999, 'Information privacy concerns, procedural fairness, and impersonal trust: An empirical investigation', Organization Science 10(1), 104-115. https://doi.org/10.1287/orsc.10.1.104

Damghanian, H., Zarei, A. \& Kojuri, M.A.S., 2016, 'Impact of perceived security on trust, perceived risk, and acceptance of online banking in Iran', Journal of Internet Commerce 15(3), 214-238. https://doi.org/10.1080/15332861.2016.1191052

De Vries, A., Erasmus, P.D. \& Gerber, C., 2017, 'The familiar versus the unfamiliar: Familiarity bias amongst individual investors', Acta Commercii 17(1), a366. https://doi.org/10.4102/ac.v17i1.366

Doney, P.M. \& Cannon, J.P., 1997, 'An examination of the nature of trust in buyer-selle relationships', Journal of Marketing 61(2), 35-51. https://doi.org/10.2307/ 1251829

Dowling, G.R. \& Staelin, R., 1994, 'A model of perceived risk and intended risk handling activity', Journal of Consumer Research 21(1), 119-134. https://doi.org/ $10.1086 / 209386$

Du, N, Huang, H. \& Li, L., 2013, 'Can online trading survive bad-mouthing? An experimental investigation', Decision Support Systems 56, 419-426. https://doi org/10.1016/j.dss.2012.10.054

Durmus, B., Ulusu, Y. \& Akgun, S., 2017, 'The effect of perceived risk on online shopping through trust and WOM', International Journal of Management and Applied Science 3(9), 103-108.

Evans, M.D., 2018, 'Forex trading and the WMR Fix', Journal of Banking \& Finance 87, 233-247. https://doi.org/10.2139/ssrn.2487991

Featherman, M.S. \& Pavlou, P.A., 2003, 'Predicting e-services adoption: A perceived risk facets perspective', International Journal of Human-Computer Studies 59(4), 451-474. https://doi.org/10.1016/S1071-5819(03)00111-3

Ginosar, A. \& Ariel, Y., 2017, 'An analytical framework for online privacy research What is missing?', Information \& Management 54(7), 948-957. https://doi. org/10.1016/j.im.2017.02.004

Gurung, A., Luo, X. \& Raja, M.K., 2008, 'An empirical investigation on customer's privacy perceptions, trust and security awareness in $\mathrm{E}$-commerce environment', Journal of Information Privacy and Security 4(1), 42-60. https://doi.org/10.1080/ 2333696X.2008.10855833 
Hanafizadeh, P. \& Khedmatgozar, H.R., 2012, 'The mediating role of the dimensions of the perceived risk in the effect of customers' awareness on the adoption of Internet banking in Iran', Electronic Commerce Research 12(2), 151-175. https// Internet banking in Iran', Electronic
doi.org/10.1007/s10660-012-9090-z

Hanafizadeh, P., Hosseinioun, S.S. \& Khedmatgozar, H.R., 2015, 'Financial valuation of a business model as an intangible asset', International Journal of E-Business Research 11(4), 17-31. https://doi.org/10.4018/IJEBR.2015100102

Hansen, J.M., Saridakis, G. \& Benson, V., 2018, 'Risk, trust, and the interaction of perceived ease of use and behavioral control in predicting consumers' use of
social media for transactions', Computers in Human Behavior 80, 197-206. https://doi.org/10.1016/j.chb.2017.11.010

Hoffman, D.L., Novak, T.P. \& Peralta, M., 1999, 'Building consumer trust online', Communications of the ACM 42(4), 80-85. https//doi.org/10.1145/299157.299175

Holst, A. \& Iversen, J.M., 2011, 'An application of a revised theory of planned behavior: Predicting the intention to use personal care products without endocrine disrupting chemicals', viewed 12 January 2019, from http://studenttheses.cbs.dk/bitstream/ handle/10417/3137/anne_hols_og_ulie_maria_iversen.pdf sequence $=1$.

Huang, S.M., Hung, Y.C. \& Yen, D.C., 2005, 'A study on decision factors in adopting an online stock trading system by brokers in Taiwan', Decision Support Systems 40(2), 315-328. https://doi.org/10.1016/j.dss.2004.02.004

Huang, Z., 2015, 'China's college students embrace stock trading, thanks to money from mom and dad', Quartz MWC Barcelona Daily Brief, viewed 12 February 2019, from https://qz.com/443527/chinas-college-students-embrace-stock-trading2019, from https://qz.com/443527/chin
thanks-to-money-from-mom-and-dad/.

Jarvenpaa, S.L., Tractinsky, N. \& Vitale, M., 2000, 'Consumer trust in an internet store', Information Technology and Management 7(1-2), 45-71. https://doi.org/ 10.1023/A:1019104520776

Kannadhasan, M., 2015, 'Retail investors' financial risk tolerance and their risk-taking behaviour: The role of demographics as differentiating and classifying factors', IIMB Management Review 27(3), 175-184. https://doi.org/10.1016/j.iimb.2015.06.004

Khan, S.U., Liu, X., Khan, I.U., Liu, C. \& Hameed, Z., 2018, 'Measuring the effects of risk and cultural dimensions on the adoption of online stock trading: A developing country perspective', International Journal of Enterprise Information System (IJEIS) 14(3), 106-127.

Kim, D.J., Ferrin, D.L. \& Rao, H.R., 2008, 'A trust-based consumer decision-making model in electronic commerce: The role of trust, perceived risk, and thei antecedents', Decision Support Systems 44(2), 544-564. https://doi.org/10.1016/j. dss.2007.07.001

Kolsaker, A. \& Payne, C., 2002, 'Engendering trust in e-commerce: A study of genderbased concerns', Marketing Intelligence \& Planning 20(4), 206-214. https://doi. org/10.1108/02634500210431595

Lease, R.C., Lewellen, W.G. \& Schlarbaum, G.G., 1974, 'The individual investor: Attributes and attitudes', The Journal of Finance 29(2), 413-433. https://doi.org/ $10.2307 / 2978811$

Lee, M.C., 2009a, 'Predicting and explaining the adoption of online trading: An empirical study in Taiwan', Decision Support Systems 47(2), 133-142. https://doi. org/10.1016/j.dss.2009.02.003

Lee, M.C., 2009b, 'Factors influencing the adoption of internet banking: An integration of TAM and TPB with perceived risk and perceived benefit', Electronic Commerce Research and Applications 8(1), 130-14. https://doi.org/10.1016/j.elerap.2008. 11.006

Liivamägi, K., 2016, 'Investor education and trading activity on the stock market', Baltic Journal of Economics 16(2), 114-131. https://doi.org/10.1080/140609 9X.2016.1189058

Litter, D. \& Melanthiou, D., 2006, 'Consumer perceptions of risk and uncertainty and the implications for behaviour towards innovative retail services: The case of internet banking', Journal of Retailing and Consumer Services 13(6), 431-443. https://doi.org/10.1016/j.jretconser.2006.02.006

Malhotra, N.K., 2010, Marketing research: An applied orientation, Prentice Hall, Upper Saddle River, NJ.

Malmendier, U. \& Nagel, S., 2011, 'Depression babies: Do macroeconomic experiences affect risk taking?' The Quarterly Journal of Economics 126(1), 373-416. https:// affect risk taking?' The Quarter
doi.org/10.1093/qje/qjq004

Mann, B.J.S. \& Sahni, S.K., 2013, 'Role of trust and customer loyalty in reducing perceived security risk in internet banking', International Journal of Electronic Business 10(4), 331-354. https://doi.org/10.1504/IJEB.2013.056783

Masipa, T.S., 2018, 'The relationship between foreign direct investment and economic growth in South Africa: Vector error correction analysis', Acta Commercii 18(1), a466. https://doi.org/10.4102/ac.v18i1.466

Maziriri, E.T., 2016, 'The influence of perceived social risk and buying behaviour on apparel store choice decision among generation $Y$ female students within the Sedibeng district', Master's dissertation, Vaal University of Technology, Vanderbijlpark.

Maziriri, E.T., Mapuranga, M. \& Madinga, N.W., 2018, 'Self-service banking and financial literacy as prognosticators of business performance among rural smal and medium-sized enterprises in Zimbabwe', The Southern African Journal of Entrepreneurship and Small Business Management 10(1), 1-10. https://doi. org/10.4102/sajesbm.v10i1.180

Mehrtens, J., Cragg, P.B. \& Mills, A.M., 2001, 'A model of Internet adoption by SMEs', Information \& Management 39(3), 165-176. https://doi.org/10.1016/S0378 7206(01)00086-6

Mekovec, R. \& Hutinski, Ž., 2012, 'The role of perceived privacy and perceived security in online market', in MIPRO, 2012 IEEE Proceedings of the 35th International Convention, Croatian Society for Information and Communication Technology, Convention, Croatian Society for Information and Communication Technology,
Electronics and Microelectronics - MIPRO, Opatija, Croatia, May 21-25, 2012, pp. 1549-1554.
Mhlophe, J.B., 2015, 'Antecedents of consumer purchase intentions towards organic food produces: A case study of the Johannesburg municipality', Master's thesis, University of the Witwatersrand, Johannesburg.

Morar, A., Venter, M. \& Chuchu, T., 2015, 'To vote or not to vote: Marketing factors influencing the voting intention of university students in Johannesburg', Journal of Economics and Behavioural Studies 7(6), 81-93.

Naiyi, Y.E., 2004, 'Dimensions of consumer's perceived risk in online shopping', Journal of Electronic Science and Technology 2(3), 177-182.

Nieman, A., 2015, 'A few South African cents' worth on Bitcoin', Potchefstroom Electronic Law Journal 18(5), 1978-2010. https://doi.org/10.4314/pelj.v18i5.25

Oliveira, T., Alhinho, M., Rita, P. \& Dhillon, G., 2017, 'Modelling and testing consumer trust dimensions in e-commerce', Computers in Human Behavior 71, 153-164. https://doi.org/10.1016/j.chb.2017.01.050

Ozkisi, H. \& Topaloglu, M., 2016, 'Identifying college students' feelings and thoughts about online shopping', Procedia Economics and Finance 39, 17-23. https://doi. org/10.1016/S2212-5671(16)30235-0

Patel, E., 2016, 'A South African perspective on the investment performance of ethical funds compared to conventional funds and investor behavior as regards ethical funds', Doctoral dissertation, University of the Witwatersrand, Johannesburg.

Pavlou, P.A., 2003, 'Consumer acceptance of electronic commerce: Integrating trust and risk with the technology acceptance model', International Journal of Electronic Commerce 7(3), 101-134.

Pennanen, K., Kaapu, T. \& Paakki, M.K., 2006, 'Trust, risk, privacy, and security in ecommerce', in Proceedings of the Frontiers of e-Business Research ICEB+ eBRF Conference, Tampere University of Technology and University of Tampere, Tampere, 28th Nov-2nd Dec.

Rahman, M.S., 2016, 'The advantages and disadvantages of using qualitative and quantitative approaches and methods in language "testing and assessment" research: A literature review', Journal of Education and Learning 6(1), 102-112.

Raosoft Incorporated, 2004, Sample size calculator, viewed 27 October 2018, from http://www.raosoft.com/samplesize.htm.

Renault, T., 2017, 'Intraday online investor sentiment and return patterns in the US stock market', Journal of Banking \& Finance 84, 25-40. https://doi.org/10.1016/j. jbankfin.2017.07.002

Rofiq, A., 2012, 'Impact of cyber fraud and trust of e-commerce system on purchasing intentions: Analysing planned behaviour in Indonesian business', Doctoral dissertation, University of Southern Queensland.

Salimon, M.G. \& Yusoff, R.Z., 2015, 'The impact of perceived security on e-trust, e-satisfaction and adoption of electronic banking in Nigeria: A conceptual review', Journal of Business and Management 17(10), 64-69. https://doi.org/10.1016/ Journal of Business and

Shanmugam, A., Savarimuthu, M.T. \& Wen, T.C., 2014, 'Factors affecting Malaysian behavioral intention to use mobile banking with mediating effects of attitude', Academic Research International 5(2), 236-253.

Sharma, J.K. \& Kurien, D., 2017, 'Perceived risk in e-commerce: A demographic perspective', NMIMS Management Review 34(1), 31-57.

Talledo, A.S., 2011, 'Computerized stock trading system for limited investors', Interactive Qualifying Projects. Degree of Bachelor of Science dissertation, Worcester Polytechnic Institute, Worcester, MA

Trattner, C., Parra, D., Eberhard, L. \& Wen, X., 2014, 'Who will trade with whom? Predicting buyer-seller interactions in online trading platforms through socia networks', in Proceedings of the 23rd International Conference on World Wide Web, ACM, Seoul, April 7-11, 2014, pp. 387-388.

Vasile, V., Teodorescu, I. \& Bucur, C., 2015, 'Aspects regarding online trading platforms in Romania: Risks and regulations', International Journal of Economic Practices and Theories 5(3), 310-313.

Veloutsou, C. \& Bian, X., 2008, 'A cross-national examination of consumer perceived risk in the context of non-deceptive counterfeit brands', Journal of Consumer Behaviour: An International Research Review 7(1), 3-20. https://doi.org/10.1002/ cb.231

Viviers, S. \& Els, G., 2017, 'Responsible investing in South Africa: Past, present and future', African Review of Economics and Finance 9(1), 122-155.

Wallace, L.G. \& Sheetz, S.D., 2014, 'The adoption of software measures: A technology acceptance model (TAM) perspective', Information \& Management 51(2), 249-259. https://doi.org/10.1016/j.im.2013.12.003

Wang, K., Wang, E.T. \& Tai, C.F., 2002, 'A study of online auction sites in Taiwan Product, auction rule, and trading type', International Journal of Information Management 22(2), 127-142. https://doi.org/10.1016/S0268-4012(01)00050-0

Wang, L.W. \& Le, Q.L., 2015, 'Customer satisfaction towards online shopping at electronics shopping malls in Vietnam- A conceptual model to enhance business success through efficient websites and logistics services. The evidence from Chinese Stock Market', Journal of Stock Forex Trade 5, 164. https://doi.org/ 10.4172/2168-9458.1000164

Wang, S.W., Ngamsiriudom, W \& Hsieh, C.H., 2015, 'Trust disposition, trust antecedents, trust, and behavioral intention', The Service Industries Journa 35(10), 555-72. https://doi:10.1080/02642069.2015.1047827

Warwick, J. \& Mansfield, P., 2000, 'Credit card consumers: College students' knowledge and attitude', Journal of Consumer Marketing 17(7), 617-626. https:// doi.org/10.1108/07363760010357813

Weideman, A., 2014, 'Innovation and reciprocity in applied linguistics', Literator: Journal of Literary Criticism, Comparative Linguistics and Literary Studies 35(1), 1-10. https://doi.org/10.4102/lit.v35i1.1074 
Wohlgemuth, V., Berger, E.S. \& Wenzel, M., 2016, 'More than just financial performance: Trusting investors in social trading', Journal of Business Research performance: Trusting investors in social trading', Journal of Busines
$69(11), 4970-4974$. https://doi.org/10.1016/j.jbusres.2016.04.061

Yamamoto, H., Ishida, K. \& Ohta, T., 2003, 'Managing online trade by reputation circulation: An agent-based approach to the $\mathrm{C} 2 \mathrm{C}$ market', in Proceedings of the 7 th World Multi-Conference on Systemics, Cybernetics and Informatics (SCl 2003), Orlando, FL, July 27-30, 2003, pp. 60-64.

Yousafzai, S.Y., Pallister, J.G. \& Foxall, G.R., 2003, 'A proposed model of e-trust for electronic banking', Technovation 23(11), 847-860. https://doi.org/10.1016/ S0166-4972(03)00130-5
Yousefi, N. \& Nasiripour, A., 2015, 'A proposed model of e-trust for electronic banking' Management Science Letters 5(11), 1029-1040. https://doi.org/10.5267/j.msl. 2015.8.008

Zheng, J., Bakker, E., Knight, L., Gilhespy, H., Harland, C. \& Walker, H., 2006, 'A strategic case for e-adoption in healthcare supply chains', International Journal of Information Management 26(4), 290-301. https://doi.org/10.1016/j.ijinfomgt. 2006.03.010

Zhong, J., Zhu, W., Wu, Y. \& Wang, K., 2012, 'Agent-based simulation of online trading', Systems Engineering Procedia 5, 437-444. https://doi.org/10.1016/j.sepro. 2012.04.066 